Journal of Teacher Education for Sustainability, vol. 19, no. 1, pp. 117-128, 2017

\title{
The Formation of Learners' Motivation to Study Physics in Terms of Sustainable Development of Education in Ukraine
}

\author{
Igor Korsun \\ Ternopil Volodymyr Hnatyuk National Pedagogical University, Ukraine
}

\begin{abstract}
This study is aimed at creating a general technique for the formation of learners' interest in physics in the context of sustainable development of education. The active means of training and active learning methods are the components of this technique. The sequence of interest formation for physics in the context of sustainable development of education was analyzed. This scheme shows the transition from a situational interest to an individual interest. Short-term objective is the formation of learners' interest in physics as a school subject. Long-term objective is the formation of learners' interest in physics as a science. Results proved that proposed technique increases the level of motivational component of the learners' cognitive activity in physics teaching. This general technique can also be used in teaching other natural sciences (e.g., Chemistry, Biology, Geography, Ecology).

Keywords: learners, sustainable development of education, motivation, physics, interest, active means, methods of training.

\section{Introduction}

Sustainable development of education is impossible without the professional competence of teachers. This provision is expressed in "Guidelines and Recommendations for Reorienting Teacher Education to Address Sustainability". "Special attention should also be paid to the training of teachers, youth leaders and other educators" (UNESCO, 2005 , p. 15). In this way, the problem of improving the teachers' professional competence is relevant in terms of sustainable development of education. First of all, this issue has been addressed in several papers in the Journal of Teacher Education and Training (e.g., Žogla, 2002; Bulajeva, 2003; Linkaityte, Zuzeviciute \& Zilinskaite, 2003; PoomValickis, Saarits, Sikka, Talts, \& Veisson, 2003; Katāne, Aizsila, \& Beitere, 2006). This problem has also been addressed in the Journal of Teacher Education for Sustainability (e.g., Kukk \& Talts, 2007; Makarevičs, 2008; Bērziņa, 2011; Iliško, Ignatjeva, \& Mičule, 2011; Salomäki, Ruokonen, \& Ruismäki, 2012).
\end{abstract}


Physics is a natural science, which is a basis of technology, and scientific and technical progress. However, a small number of learners like to study physics at schools in Ukraine. This affects the choice of professions by learners and on the prestige of professions of technical directions. Learners do not like to study physics because of the complexity of the materials. It is teachers' responsibilities to make learning physics more accessible, understandable, and interesting. In this way, the problem of motivation of the learners is relevant in education.

An analysis of educational journals makes it possible to highlight different approaches for solving the problem of the formation of learners' motivation to study physics. Fischer and Horstendahl (1997) have suggested installing a discourse oriented learning environment. Jonāne (2008) has emphasized a context of interaction between human beings, society, and environment. These aspects were introduced in the new school curriculum of Latvia. Poom-Valickis and Elvisto (2009) have investigated the problem of motivation in studying natural sciences. The authors have argued that carefully planned curriculum selection and positive learning experiences increase students' willingness to choose teacher education in natural science. Peciuliauskiene (2015) has considered physics experiments as a means of strengthening the learners' motivation for physics teaching. However, a general technique for the formation of learners' interest in physics was not realized. The aim of our work is to create a general technique for the formation of the learners' interest in physics in the context of sustainable development of education.

\section{Method}

Formation of learners' interest in physics in the context of sustainable development of education

Angelo (1993) has identified the fourteen general, research-based principles for improving higher learning. The thirteenth principle, "Motivation to learn is alterable; it can be positively or negatively affected by the task, the environment, the teacher, and the learner", speaks about the importance of learners' motivation in teaching. There are different approaches to the definition of motivation (e.g., Pintrich \& Schunk, 1996; Elliot \& Covington, 2001; Broussard \& Garrison, 2004). According to Gredler (2009), "the major approaches to the analysis of motivation share three major assumptions" (p. 392). First, a motivation is the result of interactions between environmental factors and the particular characteristics of learners. Second, the learner is an active processor of information. At the highest level, self-assessment of one's capabilities and the interpretation of information from the environment are involved in achievement-related motivation. Third, and related to the prior assumption, is that a student's motives, needs, or goals are explicit knowledge. This means that the student can reflect on these beliefs and communicate them to others (Gredler, 2009).

Pintrich and Schunk (1996) have proved that motivation is a pervasive and important determinant of behavior for students, teachers, and administrators at all educational levels. In this way, one of the most important aspects of teachers's work is the motivation of learners. "Students are likely to be more motivated to learn in your class if they see the value of what you are teaching; they believe that learning will help them achieve other important goals, that they are capable of learning it, and expect that they will succeed" (Angelo, 1993, p. 7). 
The interest of learners is the basis for the formation of their motivation to learn. Krapp, Renninger and Hoffmann (1998) have studied the interest as a habitual preference (or attitude), as a motivational belief, and as a component of the developing self. According to Krapp (2002, p. 388), an interest can be caused either by an already existing dispositional interest (individual interest) or by the special conditions of a teaching context (situational interest). This researcher has described the transition from a situational interest to an individual interest (Krapp, 2002, pp. 397-400). "Intrinsic motivation energizes and sustains activities through the spontaneous satisfactions inherent in effective volitional action" (Deci, Koestner, \& Ryan, 1999, p. 658). In accordance with these approaches, we analyze the dynamics of formation of learners' interest in physics in the context of sustainable development of education.

Lanina (1985, pp. 5-6) offers the following scheme: curiosity - active curiosity attempts to understand - strong knowledge - scientific research (Figure 1). The situational interest begins to form on the first step, "curiosity". After this step, learners show the increasing importance of the object for their interest. Thus, curiosity turns into an active curiosity. The next step, "attempts to understand", is characterized by the desire of the learners to learn more about the object or the phenomenon. The step "strong knowledge" (individual interest begins to form) is associated with volitional efforts of learners and application of knowledge in practice. The final step, "scientific research", is the highest stage of interest, during which learners formulate their own tasks and solve them.

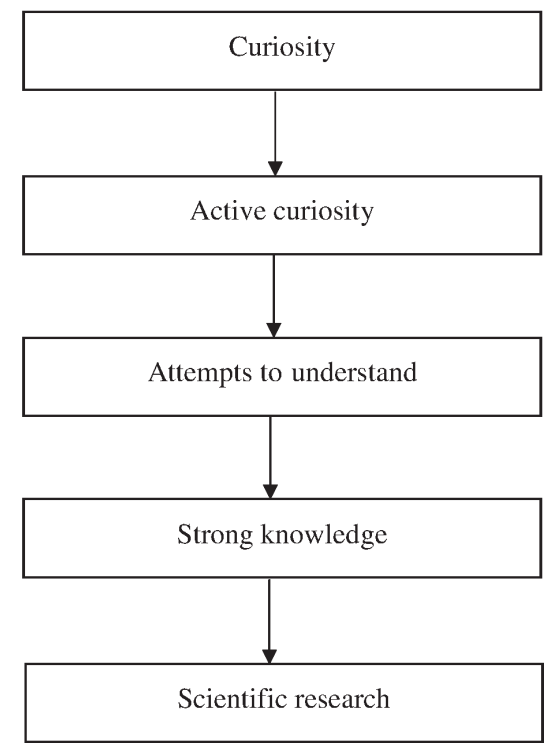

Figure 1. The scheme for the formation of learners' interest in physics

Every teacher uses its own methods for the development of learners' interest in the learning process. The level of learners' knowledge is different. The experience of one teacher cannot be mechanically transferred to another teacher. In this way, the question arises about a general technique of the formation of learners' interest in physics.

Holubova (2015) has found out that learners can be motivated by various instructional methods based on their own activity. The author proposed to use in teaching of 
physics the problem based learning, project based learning, team work, inquiry based learning, interdisciplinary approach, experiments - from very simple and low cost experiments to computer based experiments and remote laboratories. Therefore, we affirm that the learners' interest in physics is formed by appropriate active means and methods of training.

\section{Means of Training}

Lanina (1985, pp. 9-18) mentions the following criteria to foster curiosity through educational materials in physics lessons: vital importance of knowledge; study of known material from a new angle; use of the history of physics;novelty of educational material, suddenness of many conclusions and judgments; attract of learners to modern scientific research. Given these, we offer the following active means of physics training (Figure 2).

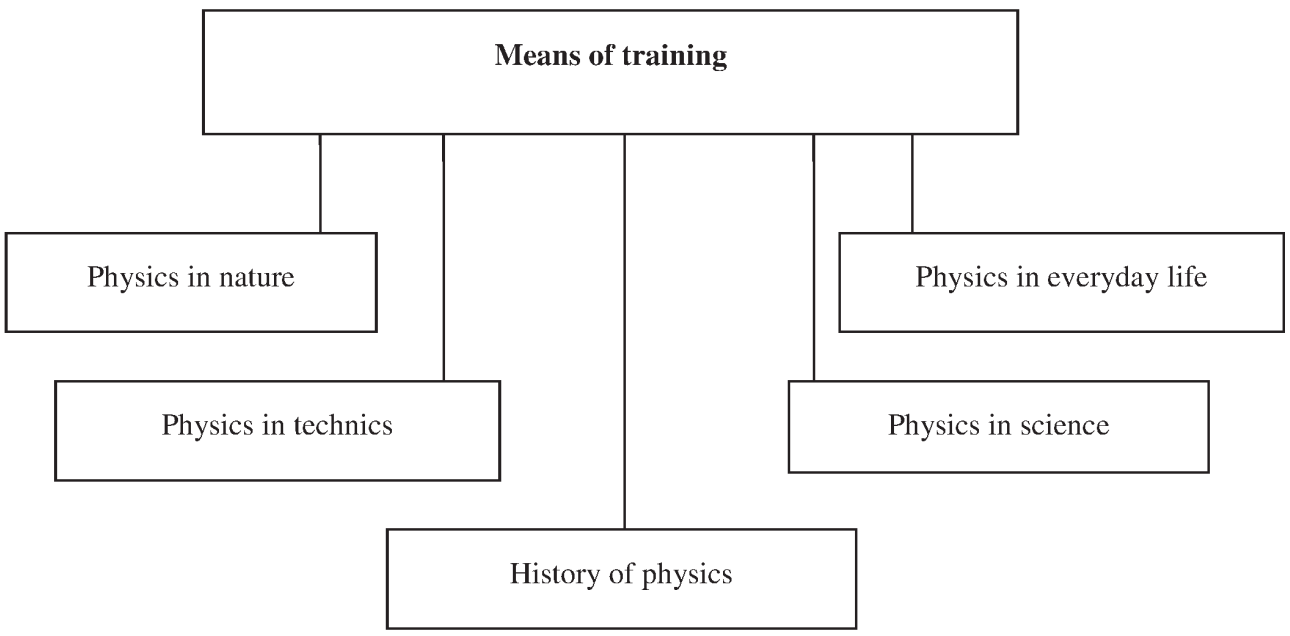

Figure 2. Active means of training for the formation of learners' interest in physics

Physics in nature: the explanation of various natural phenomena from the point of physics view. The attention of learners always attracts the application of theoretical knowledge for the explanation of phenomena in the surrounding world (Korsun, 2013).

Physics in everyday life: the explanation of various everyday phenomena from the point of physics. Shulika (2010) proposed using tasks with everyday content for the formation of learners' motivation in physics teaching.

Physics in technics: the explanation of various technical phenomena from the view point of physics. Interest will have only then a solid foundation for development, when the connection between the content of educational material and its meaning in life would find a permanent place in physics lessons (Korsun, 2009a).

Physics in science: examples of various scientific achievements, where knowledge of physics have been used. These examples show the importance of physics knowledge. It allows learners to make sure that physics made the development of technological progress possible and will facilitate the future career of learners (Kazachkova, Kasperskiy \& Polikhun, 2010). 
History of physics: has a great potential for the formation of learners' motivation to study physics (Rowcliffe, 2004; Eshach, 2009; Hong \& Lin-Siegler, 2012). The elucidation of the contribution of physicists to science would cultivate the respect to the profession of scientists (Korsun, 2017a). For many people, the ideal is a "business person", a "professional". On the other hand, "business man" must be above all a human, and then a professional. Otherwise, there can be no question about building a civilized society (Korsun, 2017b, p. 229).

\section{Learning Methods}

Education for sustainable development encourages students to develop critical thinking and take a wide-ranging, systemic and self-reflective approach, adapting to novel situations that can arise from complexity. An ability to anticipate and prepare for predictable outcomes and be ready to adapt to unexpected ones is an important goal ("Education for sustainable development: Guidance for UK higher education providers", 2014, p. 7).

Ivanova (1982, pp. 8-9) has identified three levels of learners' thinking:

(1) level of understanding;

(2) level of logical thinking;

(3) level of creative thinking.

Understanding is aimed at the assimilation of information. Learners should be able to independently analyze, summarize, argue, and explain on the level of logical thinking. Creative thinking is characterized as the ability to offer new tasks and solve them.

According to the influence on the development of learners' thinking, we selected the following active methods to teach physics (Figure 3).

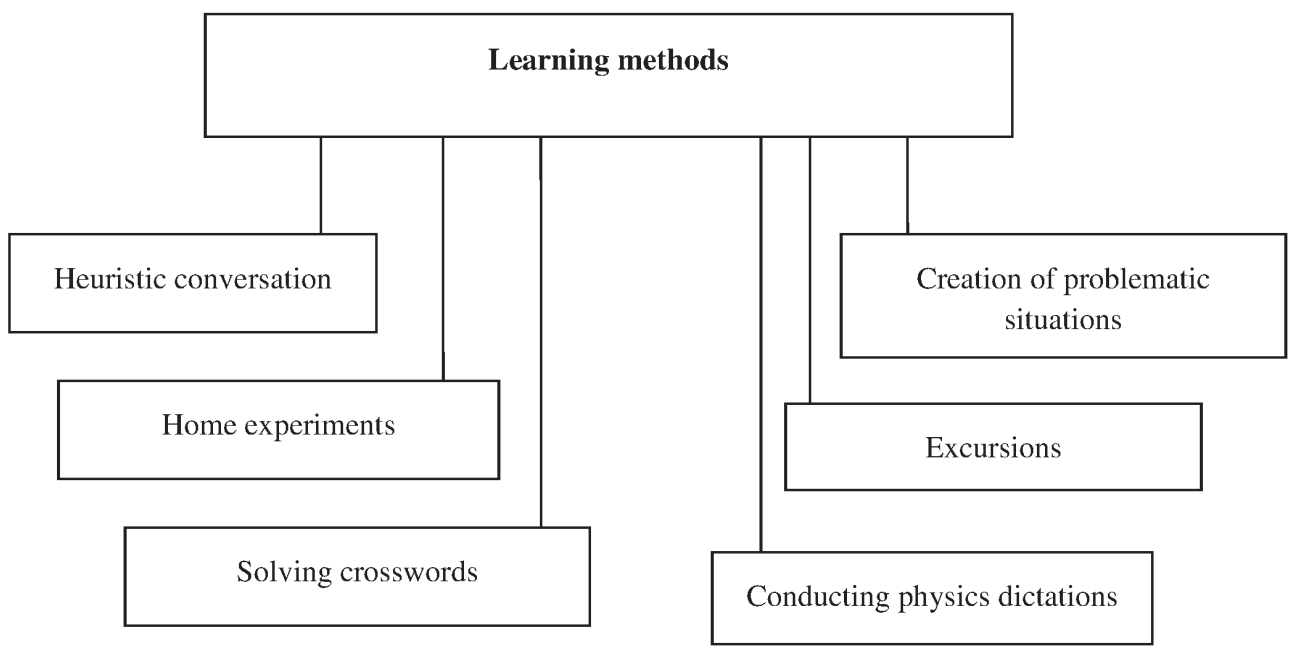

Figure 3. Active learning methods for the formation of learners' interest in physics

Heuristic conversation: Not any conversation contributes to the development of the learners' interest. The nature of a conversation is characterized by the type of questions that are posed. Sometimes the teacher poses questions for the reproduction of the learners' knowledge. Therefore, these questions do not greatly contribute to the development of 
learners' interest. Learners should be able to conduct their own analysis, synthesis, generalization, comparison, build inductive and deductive reasoning for the development of logical thinking.

Creation of problematic situations: This introduces the learners to activity, during which they are faced with facts that contradict their experience. The problem exists objectively and independently from the learner. This problem must be understood by the learner and also get personal assessment by the learner (the problem must become important for the learner). Therefore, the teacher should not only formulate the problems of a lesson, but also catch the learners' interest for the problems (e.g., the story about the everyday importance of an issue, the history of discovery).

Home experiments: Learners have a natural curiosity in reproducing experiments (Koç \& Böyük, 2012; Kazachkova, 2013). When learners will reproduce fundamental physics experiments, they will feel themselves "discoverers". They will strengthen their own the creativity, independence, and self-confidence. Criteria for selecting educational materials include safety rules, simple equipment, curiosity, accessibility, and integration in the curriculum.

Excursions: allow learners to get a complete and real picture of objects and phenomena (Korsun, 2009b, p. 76).

Solving crosswords: allows to summarize and systematize knowledge of learners in the format of a game (Korsun, 2009b, p. 69).

Conducting physics dictations: allows the teacher quickly to get objective information about the progress of learning (Korsun, 2009b, p. 69). Therefore, the teacher can adjust activities.

\section{Research Design}

The directional hypothesis of the research project is: the implementation of proposed technique will raise the level of motivational component of the learners' cognitive activity in teaching physics.

Marianenko (1992) has developed the methodology of measuring the levels of cognitive activity. This methodology is aimed to diagnose structural components of cognitive activity: motivation, content (ability and skills), and emotion. The motivational component of cognitive activity is a positive attitude of the learners to learning, cognitive interest in school subjects, and learners' desire to know and gain knowledge. The formation of thinking and cognitive processes (of perception, attention, imagination and memory) is a content of cognitive activity. The positive emotions, diligence, ability to organize their own learning, self-control, and self-improvement are the elements of the emotional component of a cognitive activity.

\section{Participants}

The pedagogical experiment was conducted in 9, 10 and 11 classes (age 15-17) during 2015-2016 academic year. Five classes formed the control group (122 learners) and five classes are the experimental group (121 learners), and these two groups took part in a pedagogical experiment. Teachers used the questionnaire method. Each learner filled in the questionnaire. The items of the questionnaire is presented in Table 1. 
Table 1

Items of the Questionnaire

$\begin{array}{lll} & \text { Items } & \text { yes no }\end{array}$

1. You can identify the physics concept (please write down an example)

2. You know an example of physics in nature (please write down an example)

3. You know an example of physics in everyday life (please write down an example)

4. You know an example of physics in technique (please write down an example)

5. You know an example of modern research on physics (please write down an example)

6. The life of any physicist is an example for you (please write down the name of physicist and explanation)

7. You know a saying of some physicist (please write down the saying)

8. You know the name of a physicist, who is a winner of the Nobel Prize in physics (please write down the name of physicist)

9. You read additional literature on physics (please write down the title of the book)

10. You know a scientific site (please write down the title of site)

Evaluation:

0-3 "yes" - low level of motivational component of the learners' cognitive activity, 4-7 "yes" - average level of motivational component of the learners' cognitive activity, 8-10 "yes" - high level of motivational component of the learners' cognitive activity.

\section{Procedure}

During the pre-test, the assessment of motivational component of the learners' cognitive activity in both groups was carried out. The training in the experimental group was carried out with the use of the developed technique, and in the control group, the training was implemented without the use of the developed technique. During post-test, the assessment of motivational component of the learners' cognitive activity in both groups was carried out.

\section{Results}

\section{Data Analysis}

There were three levels of motivational component of the learners' cognitive activity (low, average, high). The number of learners for each level has been determined. The results of experiment are presented in table 2 .

Table 2

Results of Measurements in Control Group (CG) and Experimental Group (EG)

\begin{tabular}{ccccc}
\hline \multirow{2}{*}{ Levels of motivational components } & \multicolumn{2}{c}{ Pre-test $(\%)$} & \multicolumn{2}{c}{ Post-test $(\%)$} \\
\cline { 2 - 5 } & CG & EG & CG & EG \\
\hline low & 29.5 & 29.5 & 30.7 & 17.3 \\
\hline average & 46.0 & 45.6 & 46.4 & 53.0 \\
\hline high & 24.5 & 24.9 & 22.9 & 29.7 \\
\hline
\end{tabular}

The results of the pedagogical experiment are represented in Figures 4 and 5. 


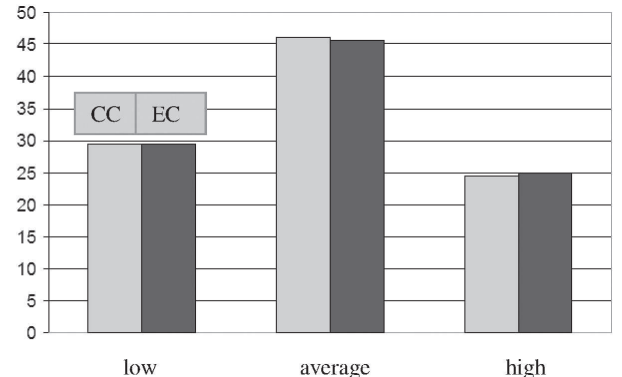

Figure 4. Results of pre-test

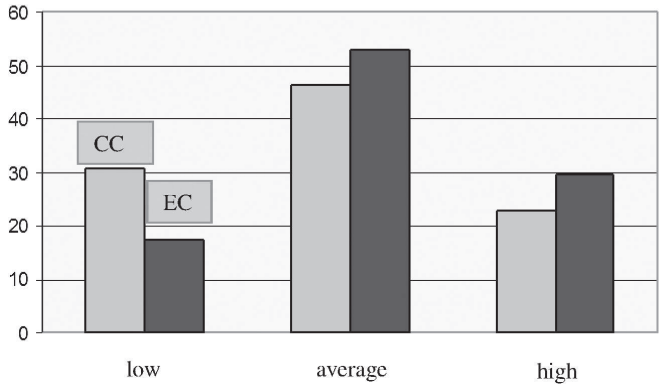

Figure 5. Results of post-test

\section{Statistical analyses}

Two statistical hypotheses were formulated to analyyze the results of the experiment:

(1) hypothesis about the absence of the difference (the null hypothesis);

(2) hypothesis about the significance of the difference (the alternative hypothesis).

We used Pearson's criterion $\chi^{2}$ for the decision about which of the hypotheses (the null or alternative) should be recognized. We conducted measurements in a three-level scale of gradation (high, average and low levels of motivational component of the learners' cognitive activity). Significance level was set 0.05 . Critical theoretical value $\chi_{0.05}^{2}$ for the level of significance 0.05 in the three-level scale of gradation is: $\chi_{0.05}^{2}=5.99$. Empirical value $\chi_{\text {empirical }}^{2}$ of measure levels of cognitive activity of CG and EG for the post-test is: $\chi_{\text {empirical }}^{2}=6.10$. Because $\chi_{\text {empirical }}^{2}>\chi_{0.05}^{2}$, then the accuracy of statistical significance of characteristics of EG and CG after the post-test is $95 \%$. Thus, the analysis of the data confirmed the alternative hypothesis: the difference between theoretical and empirical values of Pearson's criterion is due to the implementation of the developed technique.

\section{Discussion}

Education is a key element of sustainable development. As such, education is essential to individuals' development (UNESCO, 2012, p. 3). Our results showed that the high and average levels of motivational component of cognitive activity correspond with the comprehensive development of learners' personality. A low level of motivational component of cognitive activity negatively effects the level and quality of the learners' knowledge. Learners who are not motivated will not learn effectively. In this way, it is necessary to form the learners' motivation to study school subject.

There are many ways to categorize and understand the learners' cognitive processes. One of the most commonly and globally used comes from the original work of Bloom (1956), revised by Anderson and Krathwohl (2001), in which the authors identified the following cognitive processes: remembering, understanding, applying, analyzing, evaluating, and creating. The results showed that the active means of training and the active learning methods in our study could contribute to the development of the learners' cognitive processes (e.g., remembering, understanding and applying). 


\section{Conclusion}

The problem of teachers' professional competence is relevant in terms of sustainable development of education. The learner will not be able to understand the educational material, if the learner does not feel the need to study it. Therefore, it is necessary to develop the formation of the learners' interest. The sequence of interest formation for physics in the context of sustainable development of education was analyzed using the following steps: curiosity, the active curiosity, attempts to understand, strong knowledge, and scientific research. This scheme shows the transition from a situational interest to an individual interest.

The technique of strengthening the formation of learners' interest in physics in the context of sustainable development of education was developed in the present study. The active means of training and active learning methods were the components of this technique. Examples of natural phenomena, everyday life and practical use, historical materials, and examples of scientific achievements are the active means of training. Heuristic conversation, creation of problematic situations, home experiments, excursions, the solving of crosswords and conducting physics dictations are active learning methods. The results proved that proposed technique increases the level of motivational component of the learners' cognitive activity in physics teaching.

The formation of learners' motivation to study physics in the context of sustainable development of education was considered in this study. Its short-term objective was the formation of learners' interest in physics as a school subject. Its long-term objective was the formation of learners' interest in physics as a science. This should contribute to professional self-determination of learners.

\section{Recommendations}

The proposed general technique for the formation of learners' interest can be used in teaching other natural sciences (e.g., Chemistry, Biology, Geography, Ecology) for providing the sustainable development of education. Schools need to teach learners to acquire knowledge independently. Only then can we talk about sustainable development of the learners in the learning process.

\section{Acknowledgments}

The author of this article is thankful to two anonymous reviewers and language editors of the journasl for important comments and assistance with editing.

\section{References}

Anderson, L. W., Krathwohl, D. R., Airasian, P. W., Cruikshank, K. A., Mayer, R. E., Pintrich, P. R., Raths, J., \& Wittrock, M. C. (2001). A taxonomy for learning, teaching, and assessing: A revision of Bloom's Taxonomy of Educational Objectives (Complete edition). New York: Longman.

Angelo, T. A. (1993). A “teacher's dozen": Fourteen general, research-based principles for improving higher learning in our classrooms. AAHE Bulletin, 45(8), 3-13. 
Bērzina, Ž. (2011). School-based mentoring for professional development of inclusive school teachers. Journal of Teacher Education for Sustainability, 13(1), 72-83. doi: 10.2478/v10099-011-0006-0.

Bloom, B. S. (Ed.), Engelhart, M. D., Furst, E. J., Hill, W. H., \& Krathwohl, D. R. (1956). Taxonomy of educational objectives: The classification of educational goals. Handbook 1: Cognitive domain. New York: David McKay.

Broussard, S. C., \& Garrison, M. E. B. (2004). The relationship between classroom motivation and academic achievement in elementary school-aged children. Family and Consumer Sciences Research Journal, 33(2), 106-120. doi: 10.1177/1077727X 04269573.

Bulajeva, T. (2003). Teacher professional development in the context of school reform. Journal of Teacher Education and Training, 2, 39-45.

Deci, E. L., Koestner, R., \& Ryan, R. M. (1999). A meta-analytic review of experiments examining the effects of extrinsic rewards on intrinsic motivation. Psychological Bulletin, 125(6), 627-668.

Education for sustainable development: Guidance for UK higher education providers (June 2014). Retrieved from http:/www.qaa.ac.uk/en/Publications/Documents/ Education-sustainable-development-Guidance-June-14.pdf (20 January 2017).

Elliot, A. J., \& Covington, M. V. (2001). Approach and avoidance motivation. Educational Psychology Review, 13(2), 73-92.

Eshach, H. (2009). The Nobel Prize in the physics class: Science, history, and glamour. Science \& Education, 18, 1377-1393. doi: 10.1007/ s11191-008-9172-4.

Fischer, H. E., \& Horstendahl, M. (1997). Motivation and learning physics. Research in Science Education, 27(3), 411-424. doi: 10.1007/BF02461762.

Gredler, M. (2009). Learning and instruction: Theory into practice (6th ed.). Upper Saddle River, New Jersey: Prentice Hall.

Holubova, R. (2015). How to motivate our students to study physics? Universal Journal of Educational Research 3(10), 727-734. doi: 10.13189/ujer.2015.031011.

Hong, H.-Y., \& Lin-Siegler, X. (2012). How learning about scientists' struggles influences students' interest and learning in physics. Journal of Educational Psychology, 104(2), 469-484. doi: 10.1037/a0026224.

Iliško, D., Ignatjeva, S., \& Mičule, I. (2011). Teacher-carried research as a tool for teachers' professional growth. Journal of Teacher Education for Sustainability, 13(2), 87-103. doi: 10.2478/v10099-011-0016-y.

Ivanova, L. (1982). Aktivizatsiia poznavatel'noi deiatel'nosti uchashchikhsia pri izuchenii fiziki [The activization of learners' cognitive activity during the study of physics]. Moscow (in Russian).

Jonāne, L. (2008). The didactical aspects of integrated natural science content model for secondary school education. Journal of Teacher Education for Sustainability, 9, 45-57.

Katāne, I., Aizsila, A., \& Beitere, Z. (2006). Teacher competence and further education as priorities for sustainable development of rural schools in Latvia. Journal of Teacher Education and Training, 6, 41-59.

Kazachkova, N., Kasperskiy, A., \& Polikhun, N. (2010). The developing motivation in physics by means of presentation of new format "paradox show". In: GIREPIPEC-MPTL Conference, Reims, France, 291-293. 
Kazachkova, N. (2013). Non-standard implementation and physics toys as motivation stimulating egents. Naukovi zapysky [Scientific notes], 3, 25-30. Retrieved from http://www.kspu.kr.ua/download/nauk_zapiski/problemi_metod_pm/nz_ vipusk_3.pdf (10 January 2017).

Krapp, A., Renninger, A., \& Hoffmann, L. (1998). Some thoughts about the development of a unifying framework for the study of individual interest. In L. Hoffmann, A. Krapp, A. Renninger \& J. Baumert (Eds.), Interest and learning. Proceedings of the Seeon-Conference on Interest and Gender (pp. 455-468). Kiel: IPN.

Krapp, A. (2002). Structural and dynamic aspects of żnterest development: theoretical considerations from an ontogenetic perspective. Learning and Instruction, 12(4), 383-409.

Koç, A., \& Böyük, U. (2012). The effect of hands-on science experiments on attitude towards science. Journal of Turkish Science Education, 9(4), 102-118.

Korsun, I. (2009a). Pro shliakhy formuvannia piznaval'nogo interesu starshoklasnykiv do fizyky [About the ways of formation of cognitive interest of senior pupils in physics]. Collection of scientific papers Kamianets-Podilsky Ivan Obienko National University, 15, 210-212. Retrieved from http://journals.uran.ua/index.php/23074507/article/view/33426/29978 (10 January 2017) (in Ukrainian).

Korsun, I. (2009b). Aktyvizatsiia navchal'no-piznaval'noi diial'nosti starshoklasnykiv u protsesi vyvchennia vlastyvostei tverdykh til u kursi fizyky [The activization of senior pupils' educational-cognitive activity in the process of study the properties of solids in physics course]. (Candidate dissertation). National Pedagogical Dragomanov University, Kyiv (in Ukrainian).

Korsun, I. (2013). Entsyklopediia tsikavykh fizychnykh faktiv [Encyclopedia of interesting physics facts]. Ternopil: Terno-graf (in Ukrainian).

Korsun, I. (2017a). Contribution of Ukrainian scientists to the development of quantum physics. Ukrainian Journal of Physics, 62(1), 67-79. doi: 10.15407/ujpe62.01.0067.

Korsun, I. (2017b). Expediency of Study of the Scientists' Biographies in Physics Course. International Journal of Instruction, 10(2), 229-244. http://www.e-iji.net/dosyalar/ iji_2017_2_15.pdf

Kukk, A., \& Talts, L. (2007). Teachers' self-assessment of their professional skills according to the teachers' professional standard. Journal of Teacher Education for Sustainability, 8, 14-24.

Lanina, I. (1985). Formirovanie poznavatel'nykh interesov uchashchikhsia na urokakh fiziki [The formation of learners' cognitive interest in physics lessons]. Moscow (in Russian).

Linkaityte, G., Zuzeviciute, V., \& Zilinskaite, L. (2003). Professional development of teachers: Reflecting on goals. Journal of Teacher Education and Training, 2, 46-55.

Makarevičs, V. (2008). Professional competences of future teachers: perspective of different evaluators and contexts. Journal of Teacher Education for Sustainability, $10,68-78$.

Marianenko, L. (1992). Psykholohichni umovy formuvannia piznaval noi aktyunosti slabovstyhaiuchykh starshoklasnykiv [The psychological conditions of formation of the senior pupils' cognitive activity, who poorly study]. (Candidate dissertation). Institute of Psychology Ukraine, Kyiv (in Ukrainian).

Peciuliauskiene, P. (2015). Promotion of Intrinsic Motivation of New Generation Learners for Learning Physics by Digital Physics Labs. In: SOCIETY. INTEGR- 
ATION. EDUCATION. Proceedings of the International Scientific Conference, 468-479. Retrieved from http://dx.doi.org/10.17770/sie2015vol4.407 (2 December 2016).

Pintrich, P. R., \& Schunk, D. H. (1996). Motivation in education: Theory, research, and applications. Englewood Cliffs, NJ: Merrill Prentice-Hall.

Poom-Valickis, K., Saarits, Ü., Sikka, H., Talts, L., \& Veisson, M. (2003). Professional education of teachers - problems and perspectives. The Estonian Case. Journal of Teacher Education and Training, 3, 15-23.

Poom-Valickis, K., \& Elvisto, T. (2009). Students' motives and satisfaction with studies in the area of natural sciences and their willingness to continue studies in teacher education. Journal of Teacher Education for Sustainability, 11(2), 41-50.

Rowcliffe, S. (2004). Storytelling in science. School Science Review, 86(314), 121-126.

Salomäki, U., Ruokonen, I., \& Ruismäki, H. (2012). Educators’ professional and personal growth: a case study of european teachers' in-service training courses. Journal of Teacher Education for Sustainability, 14(1), 20-29. doi: 10.2478/v10099-0120002-z.

Shulika, V. (2010). Rozv'iazuvannia zadach jak vazhlyvyi chynnyk formuvannia ta rozvytku piznaval'nogo interesu uchniv [Solving of tasks as an important factor of formation and development of learners' cognitive interests]. Collection of scientific papers Kamianets-Podilsky Ivan Ohienko National University, 16, 127-130. Retrieved from http://journals.uran.ua/index.php/2307-4507/article/view/32788/ 29396 (2 December 2016) (in Ukrainian).

UNESCO (2005). Guidelines and Recommendations for Reorienting Teacher Education to Address Sustainability. Education for Sustainable Development in Action. Technical Paper No. 2, Paris: UNESCO, Education sector. Retrieved from http://unesdoc.unesco.org/images/0014/001433/143370E.pdf (10 January 2017).

UNESCO (May 2012). Education and skills for inclusive and sustainable development beyond 2015. Thematic Think Piece by UN System Task Team on the Post 2015 UN Development Agenda, Paris: UNESCO. Retrieved from http://www.un.org/ millenniumgoals/pdf/Think\%20Pieces/4_education.pdf (15 January 2017).

Žogla, I. (2002). Towards sustainability in education: Principles of teacher educators' professional development. Journal of Teacher Education and Training, 1, 47-56.

Correspondence concerning this paper should be addressed to $\mathrm{Ph}$.D. Igor Korsun, Physics and Mathematics Faculty, Ternopil Volodymyr Hnatyuk National Pedagogical University, 2 M. Kryvonos Street, Ternopil, 46027, Ukraine. Email: korsun_igor@i.ua 